Advances in Geosciences, 2, 167-171, 2005

SRef-ID: 1680-7359/adgeo/2005-2-167

European Geosciences Union

(c) 2005 Author(s). This work is licensed

under a Creative Commons License.

\title{
Multi-sensor analysis of extreme events in North-Eastern Italy
}

\author{
M. Monai, A. Rossa, G. Formentini, and S. Veronese \\ ARPAV - Regional Agency for Environmental Prevention and Protection of the Veneto - Meteorological Centre of Teolo, \\ Italy
}

Received: 24 October 2004 - Revised: 29 April 2005 - Accepted: 3 May 2005 - Published: 24 May 2005

\begin{abstract}
The North-eastern part of Italy is known to be one of the most rainy regions in Europe. In this paper three extreme events are analysed, using a multi-sensor observing system including a weather radar and a dense telemetric network of surface stations, recording precipitation, wind, temperature and relative humidity. The cases examined comprise two long lasting rainfall events impacting two distinct areas, and a vigorous hail-producing thunderstorm event over the plains. In all cases, inter-comparison between remotely sensed and surface observations, including estimates and measures of precipitation and wind, helps to better understand the behaviour of the atmosphere, thus supporting operational fore- and now-casting.

In the case of widespread precipitation, a relation is suggested between the wind speed and direction at medium/low levels with the location of the maximum precipitation relative to the mountains. This reflects the dynamical interaction between the mountain barrier and the atmospheric flux impinging upon it. This flux can be estimated by the automatic weather station of Mt. Cesen, a focal point for a now-casting of the rain in the Veneto Region. Analysis of strong thunderstorm activity makes extensive use of radar data. In the examined case the interaction of a sea breezelike circulation with a mesoscale trough gave rise to a distinct convergence line that triggered a severe and long-lived hail-producing multi-cell thunderstorm. The hail was successfully detected by the radar's hail detection algorithm.
\end{abstract}

\section{Introduction}

In the framework of the Regional Agency for Environmental Prevention and Protection of the Veneto (ARPAV), the Meteorological Centre of Teolo is the operational regional meteorological service. The duties and the aims of Meteorological Centre of Teolo comprise providing:

Correspondence to: M. Monai

(mmonai@arpa.veneto.it)
- meteorological products;

- services for the agricultural environment;

- management and development of the meteorological monitoring systems in Veneto.

In addition, the activities of the Meteorological Centre of Teolo include participation in national and international research projects for climatic risks, defence from pollution and desertification, and rural development. The Centre runs a monitoring system that includes a meteorological radar, an operative forecasting room, MSG receiving station and a network of about 200 hydro-meteorological stations. The surface station of Mt. Cesen ( $1559 \mathrm{~m}$ over the sea level) is of particular importance for the following analyses. In fact, its elevated position towards the plain (Fig. 1) to the south was found to well charactereize lower tropospheric flow with a marked meridional component (Millini et al., 1998; Barbi et al., 2005). This kind of monitoring of southerly winds is a good complement to radio sounding data at $850 \mathrm{hPa}$, in that it is more local for Veneto and available with a temporal resolution of $10 \mathrm{~min}$.

North-eastern Italy is known to be one of the most rainy areas in Europe, and of the Alpine regions (Frei and Schär, 1998). Indeed, its terrain configuration and exposition to the Adriatic Sea in cases of southerly to south-easterly flows, locally known as Scirocco winds, are conducive to heavy and long-lasting precipitation events. In such flow configurations forecast experience in the Veneto region suggests a relation between the distribution of precipitation, including the timing of its on- and offset, and the winds at particular mountain stations, e.g. Mt. Cesen, in the area (Millini et al., 1998; Veronese, 2000). Moreover, severe thunderstorm phenomena are reported to be quite frequent in the entire Po Valley, and a number of case studies can be found in the literature (e.g. Monai and Zalazar, 1993; Alberoni et al., 1996; Kurz and Dalla Fontana, 2004). Both phenomena constitute a significant forecast and nowcast challenge in terms of timing, intensity, and distribution of the associated rainfalls. 


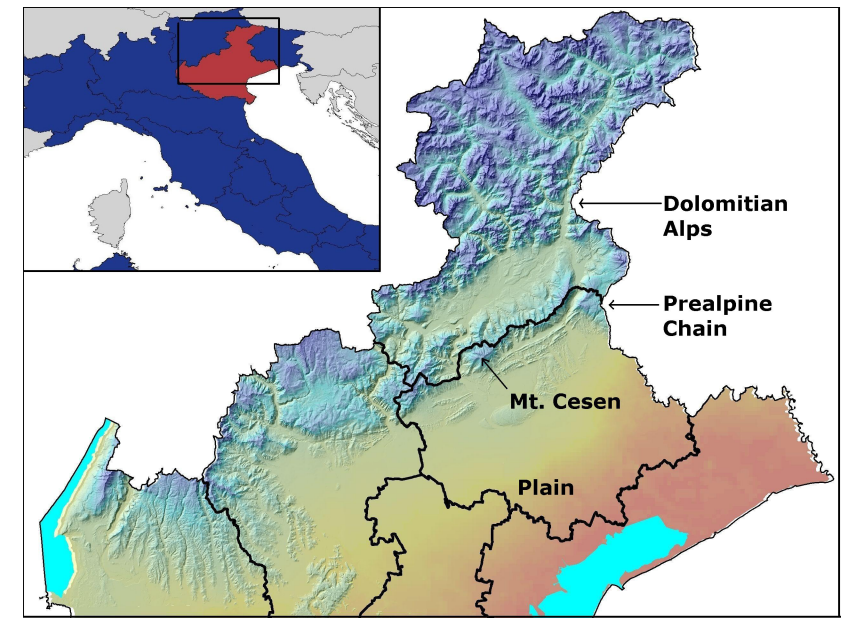

Fig. 1. Localization of the Veneto Region in north-eastern Italy, and the Mt. Cesen automatic surface weather station (1559 m). The map also evidences the topographic features of Veneto, i.e. the plain in the south, the prealpine chain which includes Mt. Cesen and, to the north, the Dolomitian Alps.

In this contribution two Scirocco cases associated with long-lasting rainfall, and one case of vigorous hail-producing convection are analysed with ARPAV's multi-sensor network, which includes a weather radar and a dense telemetric network of surface stations, recording precipitation, wind, temperature and relative humidity. These cases are described in Sects. 2 and 3, while a summary and some conclusions are reported in Sect. 4.

\section{Analysis of two cases of long-lasting rainfall}

On the southern side of the Alps, and on the Veneto Region in particular, cyclonic flow configurations developing from the north Atlantic are usually associated with significant precipitation (Kappenberger and Kerkmann, 1997; Massacand et al., 1998). In fact, the Alpine chain acts as a barrier such that a strong and humid flow from Mediterranean Sea can undergo substantial orographic enhancement, both on a regional and more local scale. The more intense events take place typically in Spring when the instability is larger, and in Autumn when the flow is very humid due to the still very warm Mediterranean. In the following two cases of long lasting and intense precipitation are reported, and attention is given to the rainfall distribution relative to the orographic barrier. The latter features, north of the plain, a prealpine ridge followed by the Dolomitian Alps, separated by a relatively flat valley, approximately $20 \mathrm{~km}$ wide (Fig. 1).

\subsection{November 2002 case}

In the period of 14-16 November 2002 an upper-level trough over the Gulf of Biscay brought a phase of perturbed weather to northern Italy, including Veneto, steering an increasingly humid southerly Sirocco flow unto the region. In particular,

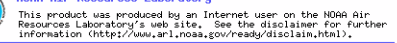

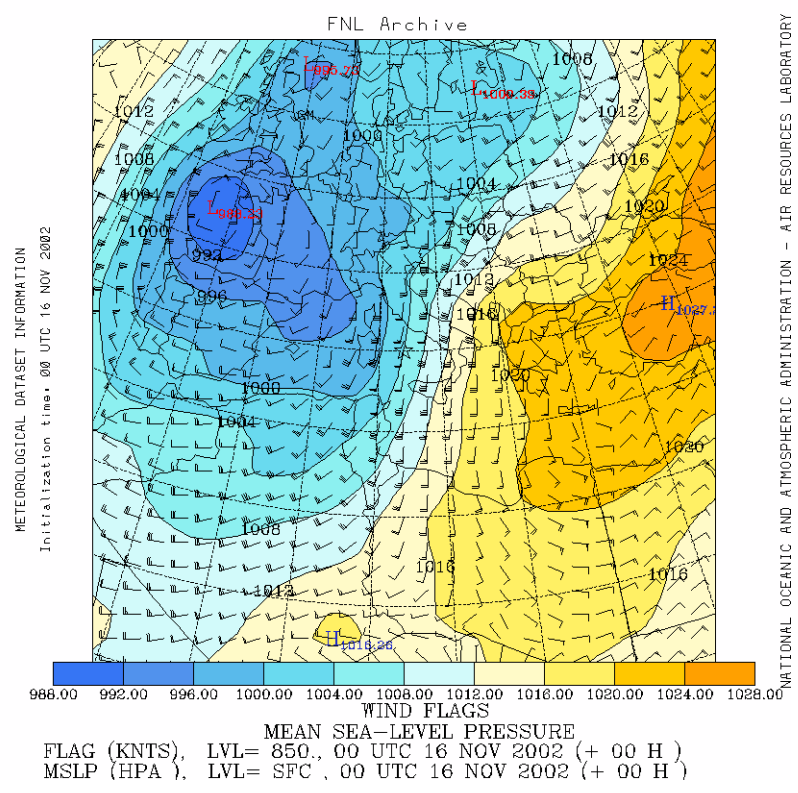

Fig. 2. Mean sea level pressure (hPa) and wind flags at $850 \mathrm{hPa}$ level - 00:00 UTC 16/11/2002 (retrieved at http://www.arl.noaa. gov/ready/).

the winds hit the Prealpine chain approximately perpendicularly starting 15 November and more makedly 16 November (Fig. 2) when instantaneous wind speeds as high as $37.0 \mathrm{~m} / \mathrm{s}$ were recorded at Mt. Cesen. The average wind speed over the three days at the same station was $10.0 \mathrm{~m} / \mathrm{s}$.

This situation produced copious precipitation, parted in showers and thunderstorms, over the mountainous part of Veneto, including the prealpine chain. The maximum was observed over the Dolomitian mountains, where $370 \mathrm{~mm}$ were recorded in three days (Fig. 3). In addition, and consistent with the warm-humid meridional flow, the snow fall limit was rather high for the season, i.e. over $2000-2200 \mathrm{~m}$. Over the upwind plain, on the other hand, no significant rain was observed in this situation.

\subsection{May 2004 case}

In the period of 5-6 May 2004 a sustained phase of perturbed weather on the Veneto Region, caused by a depression over England, featured widespread rainfall, showers and thunderstorms over the entire territory. Again, southerly winds were strong especially on the coast and in the mountains (Fig. 4), but not quite reaching the level of the November 2002 case. In fact, the Mt. Cesen surface station recorded an instantaneous maximum speed wind of $19.0 \mathrm{~m} / \mathrm{s}$, while the two-day average amounted to $7.0 \mathrm{~m} / \mathrm{s}$, i.e. well inferior in comparison to the November case. In contrast, and typical for this regime, the localization of maximum precipitation is in the central and easterly prealpine zones, rather than on the higher mountains to the north. In this case $155 \mathrm{~mm}$ were recorded 


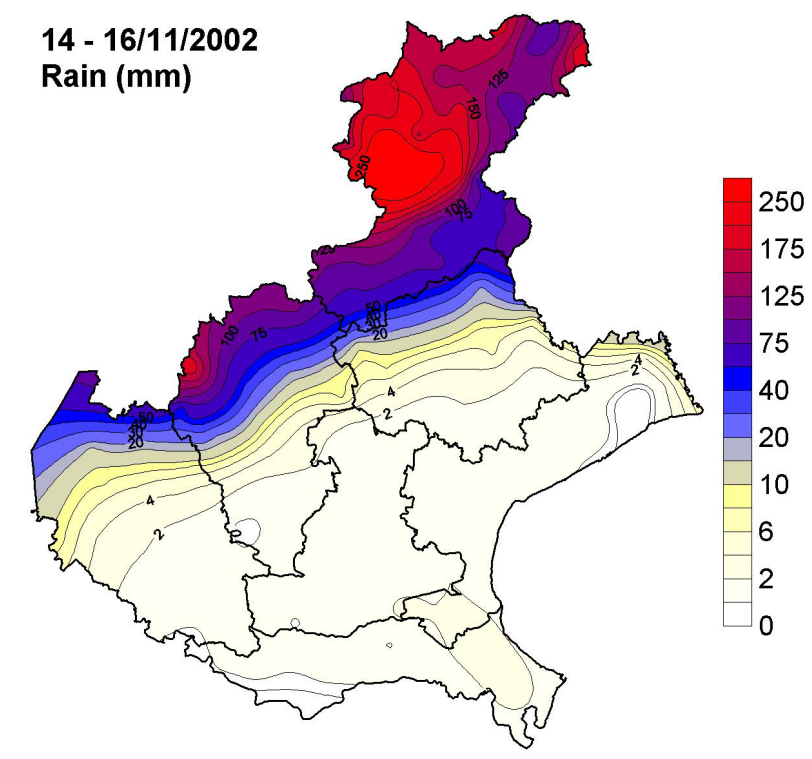

Fig. 3. Total precipitation accumulation $(\mathrm{mm})$ for the period of 14 16 November 2002 as observed by the ARPA Veneto rain gauge network.

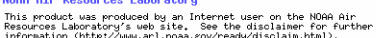

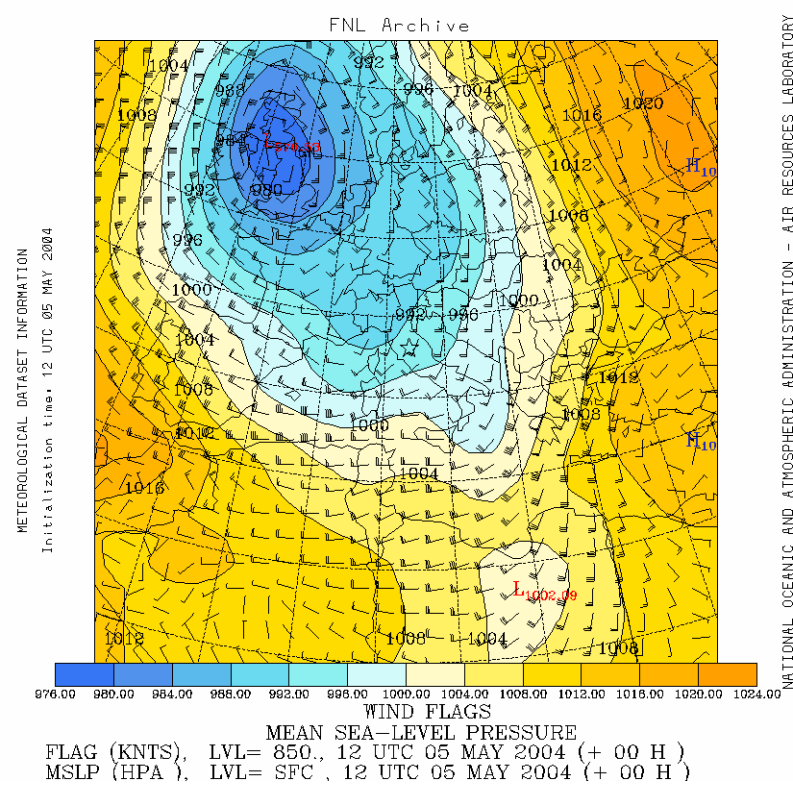

Fig. 4. Mean sea level pressure (hPa) and wind flags at $850 \mathrm{hPa}$ level - 12:00 UTC 05/05/2004 (retrieved at http://www.arl.noaa. gov/ready/).

in two days (Fig. 5). The snow limit was generally around $1400 / 1600 \mathrm{~m}$, but locally even lower in the Dolomitian valleys in the presence of showers and thunderstorms. Also, rain was observed over the plains, with more significant amount in the north-westerly and central parts and lesser amounts in the south-easterly parts.

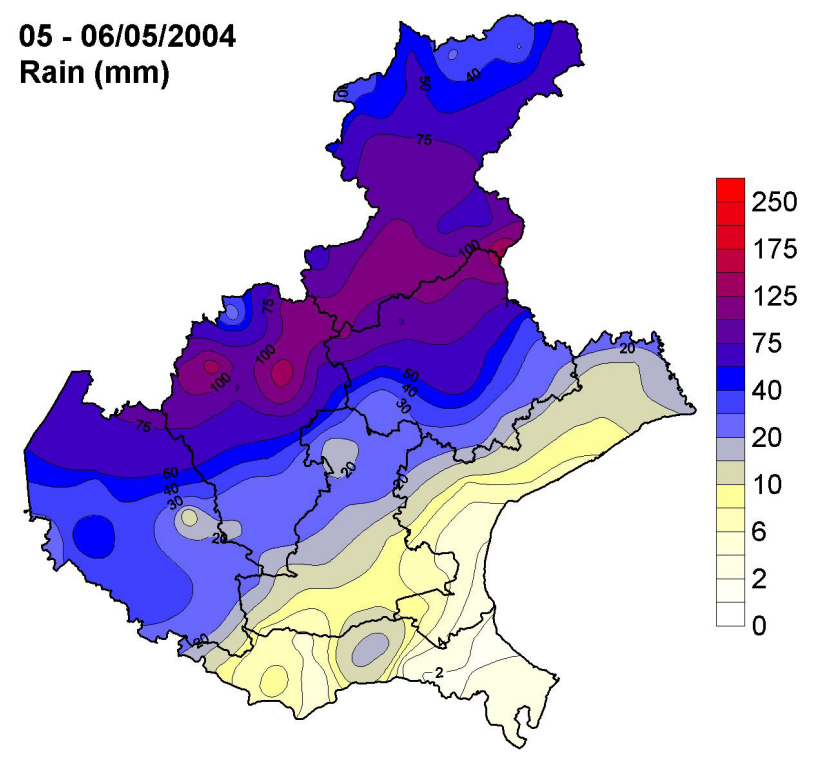

Fig. 5. Total precipitation accumulation $(\mathrm{mm})$ for the period of 5-6 May 2004 as observed by the ARPA Veneto rain gauge network.

\section{Synoptic situation of 28 August 2003 hailstorm event}

A wide through extended from the Scandinavian peninsula to the gulf of Biscay, with significant cold air advection in the middle troposphere. The anticyclonic subtropical ridge is stationary over the southern part of the Mediterranean Sea and North Africa. Between the two structures a southwesterly flux with moderate cyclonic curvature was established just on northern Italy. A jet stream was present at the $300 \mathrm{hPa}$ level with wind velocities of about $60-70$ knots. At the $850 \mathrm{hPa}$ level there was considerable subtropical warm advection while the cold front was situated between France and Spain. At mid-tropospheric levels there was a mesoscale trough featuring a WSW-ENE oriented axis. This resulted in a transport of cyclonic vorticity at the trough's leading edge, where a small area of cold air, associated with the previous airmass, survived just over the Triveneto region, therefore setting up conditions that favour convection.

At the surface, a trough extended from the Piedmont Region to North-Eastern Italy not displaying any frontal signature, but exhibiting a clear convergence line, as depicted by ARPAV's surface network (Fig. 6). Warm and wet southeasterly sea breeze like currents from the Adriatic Sea were present in the eastern part of the Veneto Region, meeting dry westerly currents and cold north-easterly currents originating from the Trentino and Friuli regions (Fig. 7). In this setup the vertical motions were triggered in the convergence line giving rise to the subsequent development of a particularly vigorous, hail-producing multi-cell pre-frontal thunderstorm. This is a typical thunderstorm event with dynamic triggering by a surface-level shear line associated with the passage of a mesoscale trough. The interaction of its accompanying 


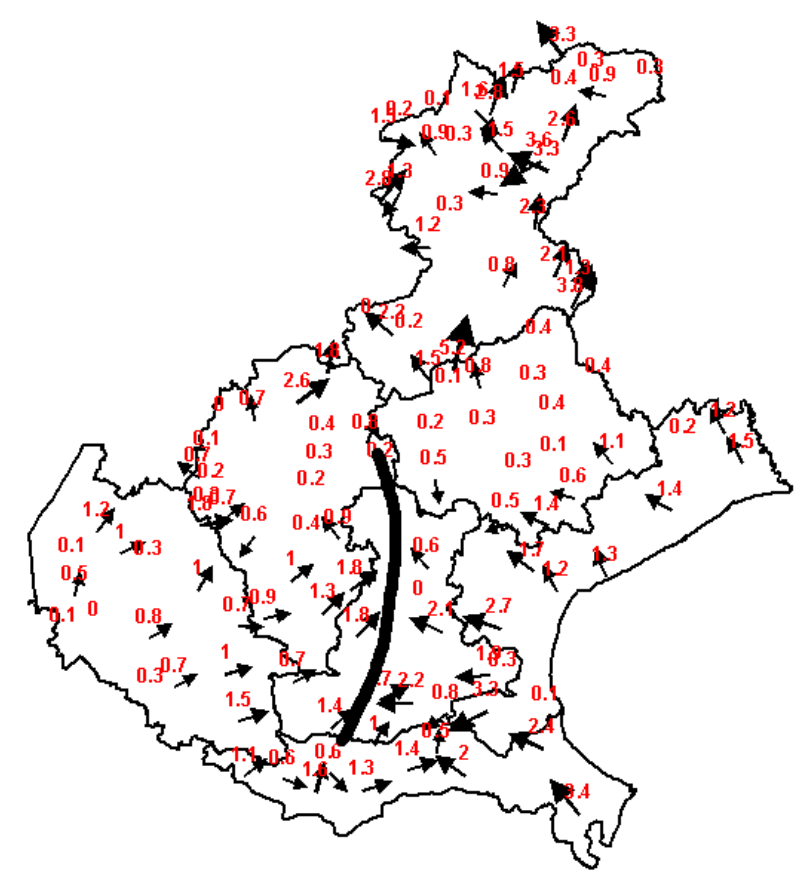

Fig. 6. Surface wind observations of the ARPAV automatic weather station network for 28 August 2003, 15:00 UTC. The numbers denote wind speed $(\mathrm{m} / \mathrm{s})$. The thick line delineates the convergence line (see text).

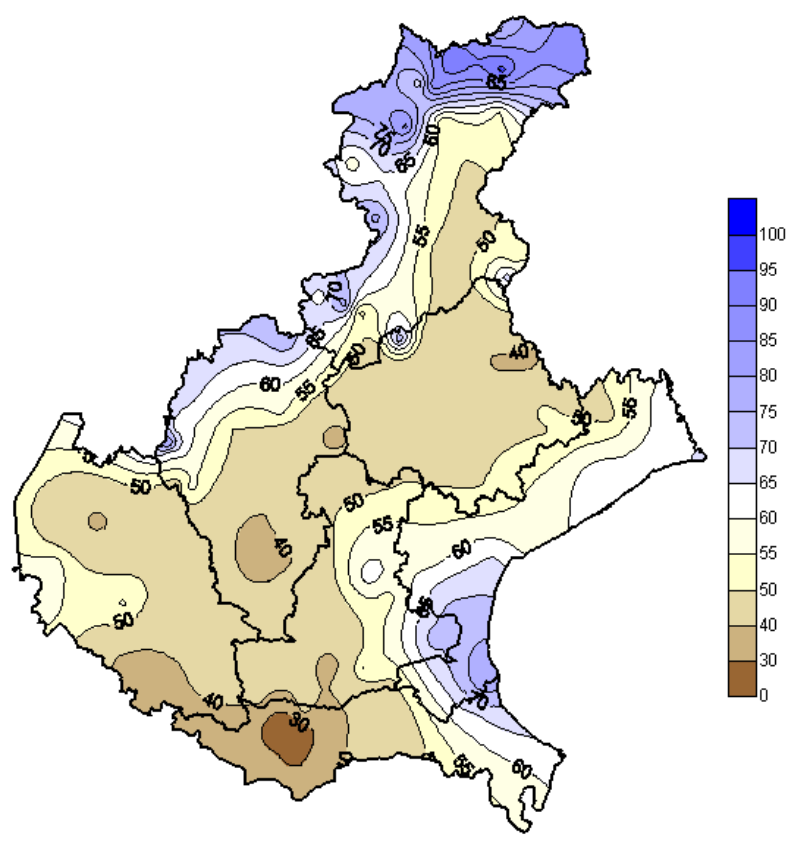

Fig. 7. As in Fig. 6 for relative humidity (\%).

flow with the Adriatic sea-breeze circulation is a possible enhancement of this type of trigger. Unlike in frontal cases, this type of event did not exhibit any subsequent cooling or wind rotation.

Moreover, inspection of the radar images shows that the thunderstorm originated at 16:30 UTC in an area south of the Colli Euganei. Radar scans available every ten min-

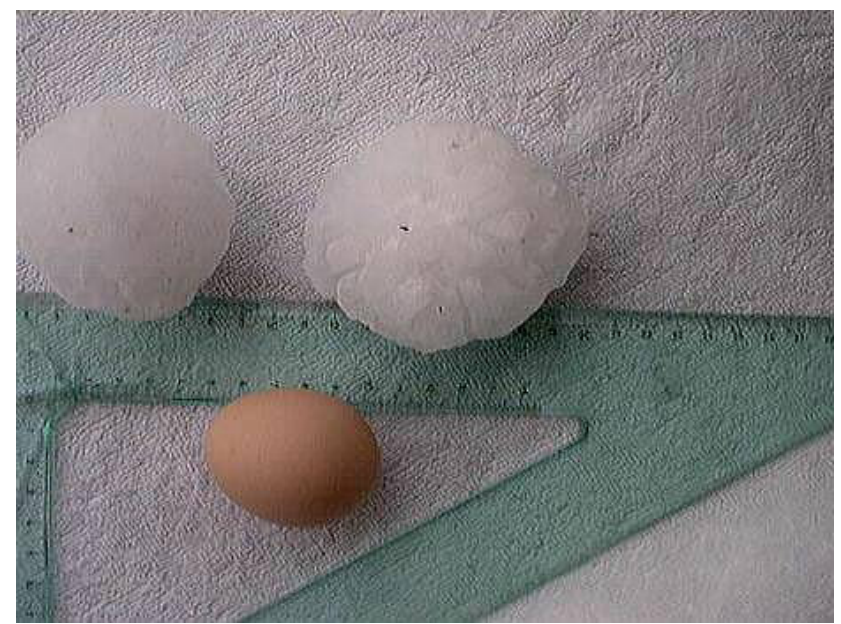

Fig. 8. Hailstones with diameters as large as $8 \mathrm{~cm}$ photographed by Paolo Nalin in the city of Padua 28 August 2003.

utes show that the thunderstorm went around the Colli Euganei in a SSW-NNE direction; at 17:30 UTC the system attained its maximum intensity south of the city of Padua, where hailstones with a diameter as large as $8 \mathrm{~cm}$ were observed (Fig. 8). Vertical section analysis (Fig. 9) reveals the presence of radar echoes with reflectivity values over $60 \mathrm{dBZ}$ at a height of $7 \mathrm{~km}$ and values over $45 \mathrm{dBZ}$ up to $12 \mathrm{~km}$. The EDGE HAILP (hail probability) algorithm diagnoses the hail potential based upon echo top height, melting level height, relative humidity and wind speed at the $500 \mathrm{mb}$ level. This proprietary EEC algorithm is a simple linear regression of these meteorological and radar parameters. It diagnoses hail probabilities over $90 \%$ in more than one area with an absolute maximum over $99 \%$. After passing over the city of Padua, the convective system continued towards the NNE passing over southern part of the town of Treviso at 18:30 UTC producing hail with diameters up to $6 \mathrm{~cm}$.

\section{Summary and conclusions}

In the present study, three cases of intense precipitation have been examined by analysing data coming from ARPAV's multi-sensor observational network. In the case of situations with significant Scirocco winds, the experience collected in the past few years suggests that the wind observation at the Mt. Cesen surface station is a useful indicator for the localization of the maximum precipitation signal. For not so strong Scirocco winds, the maximum rainfall is expected over the Prealps with possible weaker signals over the plain. In case of more intense Scirocco winds, the maximum rainfall tends to be shifted onto the Dolomitian mountains while no significant signal is expected over the plain. Analysis of a strong thunderstorm case, making extensive use of radar data, yielded a good performance of the hail probability estimation algorithm, pinpointing the areas where most severe hail fall was reported. In the examined case the interaction of a sea breeze-like circulation with a mesoscale trough gave 


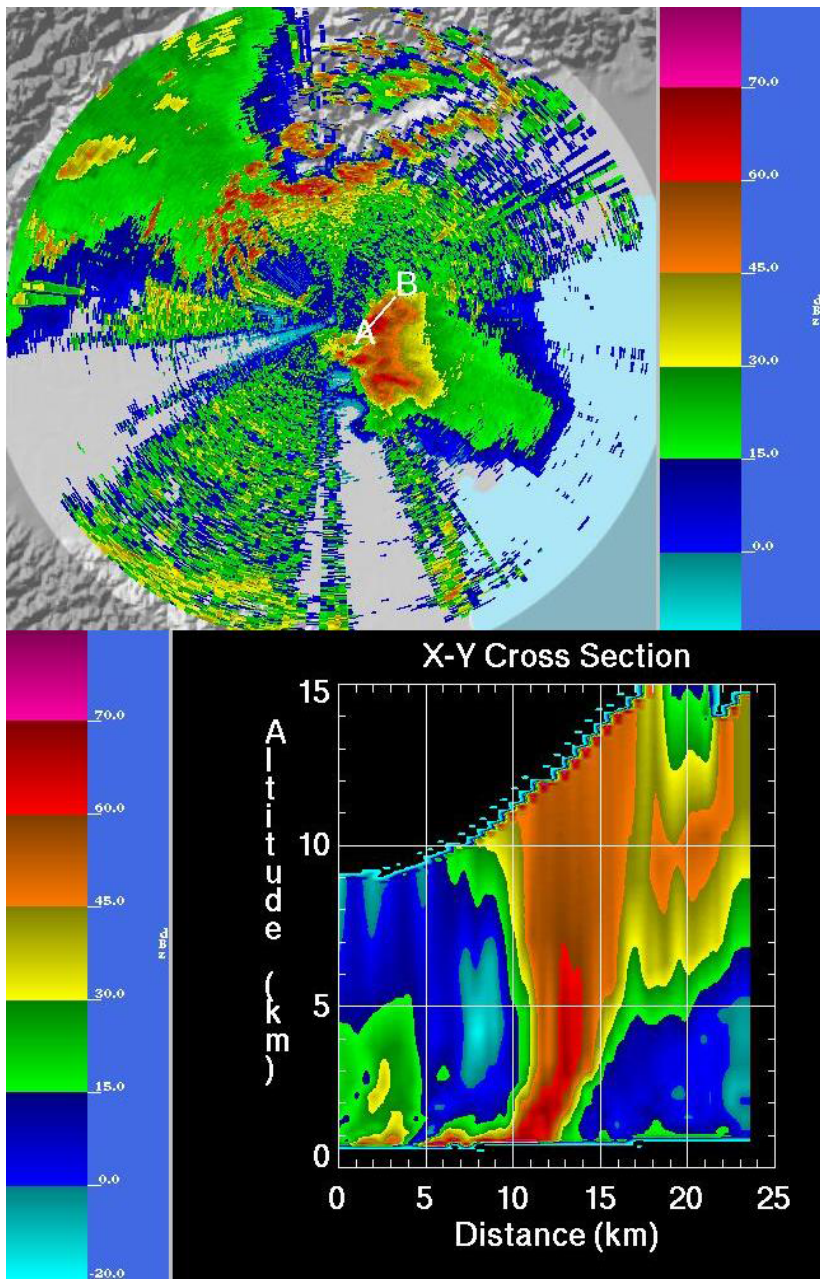

Fig. 9. Horizontal maximum reflectivity in $\mathrm{dBZ}$ (top panel) and cross section A-B (bottom panel) as observed by the ARPAV Mt. Grande C-band radar, 28 August 2003, 17:30 UTC.

rise to a distinct convergence line that triggered a severe and long-lived multi-cell thunderstorm.

An obvious limitation of the present work is its confinement to a very limited number of case studies. In order to substantiate the findings, more cases need to be investigated, and a conceptual understanding needs to be aimed at.

Results of such analyses can be significant for operational applications, not only at Veneto's regional scale but, potentially, also in a larger context, e.g. in the framework of an existing project for a National Surveillance System in Italy. Furthermore, an upgrading of the weather monitoring system in the Veneto Region is in progress and will include improving real-time capabilities of surface stations, installing a second radar, and setting up a network of temperature and wind profilers. Such action will significantly improve local capability of monitoring and nowcasting not only for hydrometeorological extreme events but also for environmental emergencies like atmospheric pollution problems.

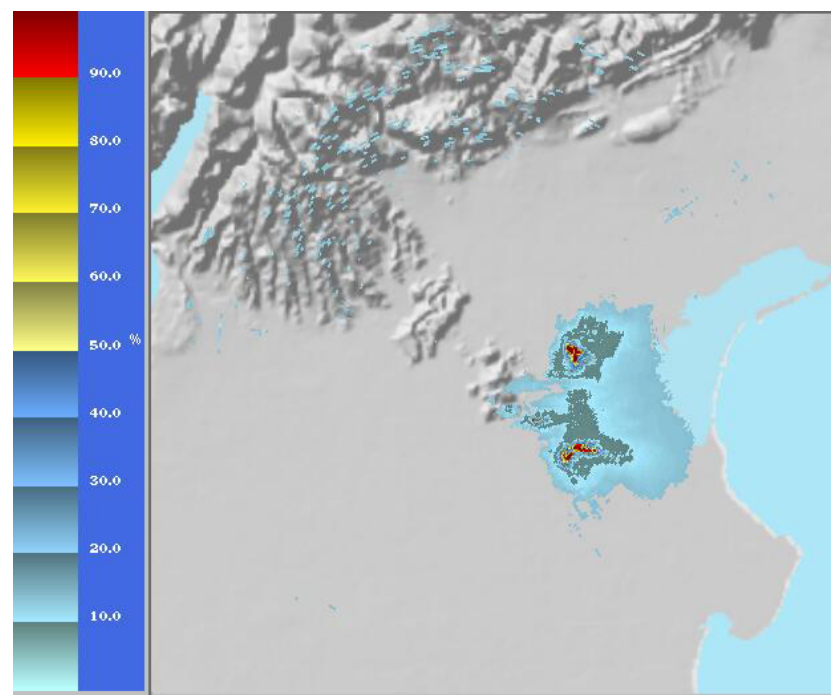

Fig. 10. The EDGE HAILP evaluated at 28 August 2003 17:30 UTC; this product diagnoses the probability (\%) for the occurrence of hail.

\section{References}

Alberoni, P. P., Levizzani, V., Watson, R., Holt, A., Costa, S., Mezzasalma, P., and Nanni, S.: The 18 June 1997 companion supercells: Multiparametric Doppler radar analysis, Meteor. Atmos. Phys., 75, 101-120, 2000.

Barbi, A., Bonan, A., Millini, M., and Rossa, A.: Characterization of intense precipitation event over small scale, southern Alpine river catchments, Croatian Meteorological Journal, 40, 141-144, 2005.

Frei, C. and Schär, C.: A precipitation climatology of the Alps from high-resolution rain-gauge observations, Int. J. Climatol., 18, 873-900, 1998.

Kappenberger, G. and Kerkmann, J.: Il tempo in montagna - manuale di meteorologia alpina (pp 124-126), Zanichelli, 255 pp., 1997.

Kurz, M. and Dalla Fontana, A.: A case of cyclogenesis over the western Mediterranean Sea with extraordinary convective activity, Meteorological Applications, June 2004, Vol. 11, No. 2, 97 113, 2004.

Massacand, A. C., Wernli, H., and Davies, H. C.: Heavy precipitations on the Alpine southside: an upper level precursor, Geophys Res. Lett., 25, 1435-1438, 1998.

Millini, R., Monai, M., and Renon, B.: Relationship between rainfall and wind on Eastern Alps, Proceedings of the 25th Int. Conference of Alpine Meteorology, Torino, Italy, 14-19 September, 74-78, 1998.

Monai, M. and Zalazar, E.: Studio di alcuni eventi temporaleschi intensi verificatisi sul Veneto nel quadriennio 1988-91, Regione del Veneto (Dipartimento per l'agrometeorologia) e Centro sperimentale per l'idrologia e la meteorologia, Teolo, Padova, Italia, 1993.

Veronese, S.: Correlazione tra il vento in quota e la variazione dell'intensità di precipitazione al suolo, Tesi di Laurea, Università degli Studi di Padova, Italia, 2000. 